УДК 623.974

DOI: $10.33099 / 2707-1383-2020-35-1-20-33$

ФРОЛОВ С. М., капітан 1 рангу, кандидат історичних наук, дочент кафедри Військово-Морських Сил Національного університету оборони України імені Івана Черняховського (м. Київ) ORCID: 0000-0001-9873-4413

\title{
ЗАСТОСУВАННЯ ЧАСТИН СПЕЦІАЛЬНОГО ПРИЗНАЧЕННЯ ВІЙСЬКОВО-МОРСЬКИХ СИЛ ЗБРОЙНИХ СИЛ УКРАЇНИ В АНТИТЕРОРИСТИЧНІЙ ОПЕРАЦІЇ НА ТЕРИТОРІЇ ДОНЕЦЬКОЇ ТА ЛУГАНСЬКОЇ ОБЛАСТЕЙ (2014-2016 рр.)
}

В умовах проведення операиії Об'єднаних сил на території Донецької та Луганської областей, одним із пріоритетних і актуальних завдань у справі розбудови Військово-Морських Сил Збройних Сил України (далі - ВМС ЗС Украӥни) є розвиток військових частин спеиіального призначення.

Досвід бойових дій під час антитерористичної операиії на території Донеиької та Луганської областей продемонстрував широке застосовування частин спеціального призначення ВМС ЗС України, зокрема, морського иеентру спеціального призначення та окремого загону боротьби з підводними диверсійними силами та засобами.

Актуальність даної теми зумовлюється необхідністю вивчення досвіду застосування підрозділів морського иентру спеціального призначення та окремого загону боротьби з підводними диверсійними силами та засобами ВМС ЗС України під час антитерористичної операції на території Донецької та Луганської областей, що, на нашу думку, є підтрунтям для подальшого розвитку частин спеціального призначення ВМС ЗС України.

На підставі відкритих джерел запропоновано висвітлити досвід застосування підрозділів морського иентру спеціального призначення та окремого загону боротьби з підводними диверсійними силами та засобами ВМС ЗС України у ході антитерористичної операиії на території Донеиької та Луганської областей та надати рекомендаиії щодо застосування їх у сучасних умовах.

Проведено аналіз завдань, які були покладені на вищеозначені підрозділи. Встановлено, що особовий склад частин спеціального призначення ВМС ЗС Украӥни був нагороджений державними нагородами за виконання бойових та спеціальних завдань. Висвітлено бойові втрати особового складу частин спеціального призначення ВМС ЗС України. 
Надані рекомендаиії щзодо застосування підрозділів частин спеціального призначення ВМС ЗС Украӥни в сучасних умовах.

Бойовий досвід частин спеціального призначення ВМС ЗС України в антитерористичній операції на території Донецької та Луганської областей дозволить уникнути недоліків і прорахунків під час реформування відповідних частин флоту.

Ключові слова: застосування, морський центр спеціального призначення, окремий загін боротьби з підводними диверсійними силами та засобами, Військово-Морські Сили Збройних Сил Украӥни, антитерористична операиія, військова розвідка.

Постановка проблеми. Одним із пріоритетних завдань, передбачених Стратегічним оборонним бюлетенем України та Планом дій щодо впровадження оборонної реформи у 20192020 рр., є виконання Оперативної цілі 3.6. Відродження військово-морського потенціалу держави, зокрема, завдання 3.6.1. Формування військово-морських спроможностей України, адекватних загрозам та достатніх для забезпечення оборони морського узбережжя Азовського моря [1;2]. Для виконання цього завдання, на думку автора, у ВМС ЗС України необхідно розвивати військові частини спеціального призначення, які повинні зайняти гідне місце у структурах національного флоту.

Аналіз останніх досліджень і публікацій 3 вищезазначеної теми свідчить, що в них розглядаються як позитивні, так і негативні аспекти застосування частин спеціального призначення ВМС ЗС України під час АТО [3, с. 20-84; 4]. Поряд із цим їх автори не здійснювали аналіз бойових завдань, що були покладені на особовий склад цих військових частин та не надавали рекомендацій щодо їх подальшого застосування в умовах проведення операції Об'єднаних сил.

Актуальність даної теми обумовлюється необхідністю вивчення бойового досвіду застосування частин спеціального призначення ВійськовоМорських Сил Збройних Сил України в ATO на території Донецької та Луганської областей для подальшого розвитку частин спеціального призначення ВМС ЗС України.

Мета статті полягає в тому, щоб на підставі відкритих джерел висвітлити досвід застосування частин спеціального призначення ВМС ЗС України у ході ATO на території Донецької та Луганської областей та надати рекомендації щодо застосування їх у сучасних умовах.

Виклад основного матеріалу. У 2014 році до складу ВМС ЗС України входили наступні військові частини спеціального призначення: морський центр спеціального призначення (далі - мц СпП) та окремий загін боротьби 
3 підводними диверсійними силами та засобами (далі - озаг бПДСЗ).

3'ясовано, що мц СпП призначений для проведення розвідувально-диверсійних дій на території противника 3 морського напряму, захоплення та знищення берегових споруд, кораблів (суден) та виконання інших завдань [5, c. 97-103]. Призначенням озаг бПДСЗ є пошук та знищення підводно-диверсійних сил і засобів противника на акваторіях пунктів базування та на ближніх підходах до них самостійно або у взаємодії з іншими силами [6, с. 74-84].

Незважаючи на особливість призначення зазначених військових частин, 3 початком проведення АТО на території Донецької та Луганської областей підрозділи цих частин були залучені для виконання бойових завдань виключно на сухопутному напрямку.

Про перший бойовий досвід в АТО, який отримав особовий склад звідного загону від мц СпП ВМС ЗС України згадується у липні 2014 р. Так, 21 липня 2014 р. штурмова група на чолі 3 капітаном 1 рангу Шевченком Є. Г. у складі 33 спецпризначенців від мц СпП BMC та 8 спецпризначенців окремого центру сил спеціальних операцій 3С України отримала наказ увійти у Дзержинськ (зараз Торецьк - прим. автора), провести зачистку та звільнити місто від незаконних збройних формувань (далі - НЗФ). Розвідники з боєм провели зачистку міських вулиць, захопили в полон 7 бойовиків та зайняли будівлю районної державної адміністрації міста. Цю будівлю вони протягом 8-и годин утримували під атаками загону НЗФ у кількості понад 200 осіб, до вогневої підтримки якого входили 2 танки, БМП, БТР, міномети та снайпери. У ході бою спецназівцями та завдяки корегуванню ударів авіації та артилерії за різними оцінками було знищено до 150 бойовиків НЗФ. Завдання зі звільнення міста було виконано 3 мінімальними втратами, внаслідок бою троє розвідників дістали поранення [3 с. 23-29; 7; 8; 9]. Але слід констатувати, що вони виконували типові завдання механізованих підрозділів та військових частин Сухопутних військ Збройних Сил України.

Перше офіційне згадування про участь у війні на Донбасі особового складу мц СпП ВМС ЗС України було опубліковано в Указі Президента України від 8 серпня 2014 року № 640/2014 "Про відзначення державними нагородами України”, в якому за особисту мужність і героїзм, виявлені у захисті державного суверенітету та територіальної цілісності України нагороджено орденом “За мужність” III ступеня чотирьох розвідників центру, зокрема, капітана 1 рангу Шевченка Едуарда Григоровича, капітан-лейтенанта Шевчука Євгена Олександровича, старшину 1 статті Савченка Сергія Сергійовича, старшину 1 статті Шевченка Анатолія Михайловича та медаллю "За військову службу Україні” старшого матроса Кіору Олега Ігоровича [10; 11, с. 144]. Автор припускає, що нагороджені розвідники мц СпП почали успішно проводити розвідувально-диверсійні дії в інтересах сил АТО значно раніше від 
першого публічного згадування, тому інформація про обставини та результати цих дій $є$ закритою.

Встановлено, що в період часу, що розглядається у статті, підрозділи мц СпП виконували завдання у різних секторах АТО. 3'ясовано, що влітку 2014 р. на базі роти охорони центру було сформовано відділення охорони та обслуговування органів військової контррозвідки Служби безпеки України. На чолі $з$ командиром мц СпП особовий склад цього підрозділу брав безпосередню участь у бойових діях проти НЗФ у Старобешевському, Амвросіївському, Тельманівському районах, а також на Савур-Могилі, успішно виконуючи завдання військової розвідки в інтересах угруповань військ на сухопутному напрямку. У серпні 2014 р. особовий склад центру зазнав перших втрат. Так, 13 серпня 2014 р. від кульового поранення під час звільнення с. Грабське Амвросіївського району Донецької області загинув матрос Красов Дмитро Володимирович. Нагороджений орденом “За мужність” III ступеня (посмертно). А вже 16 серпня 2014 р. внаслідок обстрілу базового табору 40 батальйону територіальної оборони в районі смт Старобешеве Донецької області з РСЗВ “Ураган” загинув матрос Корнафєль Євген Вадимович, нагороджений орденом “За мужність” III ступеня (посмертно). 17 серпня від отриманих поранень помер командир мц СпП капітан 2 рангу Зінченко Олексій Володимирович [12; 13]. Його нагороджено орденом Богдана Хмельниць- кого III ступеня (посмертно). Під час цього обстрілу також був важко поранений старший мічман Шкодін Сергій Анатолійович, який в подальшому проходив довготривалий курс лікування та реабілітації. Нагороджений орденом “За мужність” III ступеня [14; 15; 16].

В район Іловайська підрозділ мц СпП у складі 30 осіб прибув після 24-го серпня 2014 року. Особовий склад залучався до типових завдань військової розвідки, зокрема, виявлення стану та положення НЗФ. Під час виконання цих завдань розвідувальними групами спеціального призначення (РГ СпП) центру було виявлено рух колон механізованих підрозділів Збройних Сил Російської Федерації у напрямку Іловайська. Про виявлене негайно була зроблена доповідь вищому командуванню. Під час боїв за Іловайськ двоє офіцерів мц Спп загинули. Так, капітан 3 рангу Заграничний Валентин Анатолійович загинув 28 серпня 2014 р., його група потрапила у засідку під с. Червоносільське. Нагороджений орденом “За мужність” III ступеня (посмертно). Капітан-лейтенант Костюк Володимир Миколайович загинув 29-го серпня 2014 р. під час виходу 3 Іловайського котла т. зв. “Зеленим коридором" в районі с. Новокатеринівка. Нагороджений орденом "За мужність” III ступеня (посмертно). Троє військовослужбовців потрапили в полон, але вже 27 вересня 2014 р. вони були звільнені та передані українській стороні. Всього вийшло 25 розвідників, у т. ч. 6 поранених та контужених [3, с.36; 17; $18 ; 19 ; 20]$. 
У вересні 2014 р. на Маріупольському напрямку під керівництвом командира мц СпП ВМС ЗС України капітана 1 рангу Юрія Борисовича Олефіренка було розгорнуто загін СпП із завданнями ведення військової та спеціальної розвідки. Розвідники успішно виконували бойові завдання на непідконтрольній українським військам території, коригували вогонь артилерії, виявляли та знищували НЗФ. Прикладом особистого героїзму та професіоналізму став вчинок капітана 1 рангу Ю. Олефіренка. Так, 16 січня 2015 року під час виконання завдання 3 коригування артилерійського вогню по позиціях бойовиків поблизу с. Павлополя Новоазовського району Донецької області Юрій Борисович за допомогою безпілотного літального апарату виявив місце розташування ворожої мінометної батареї. Завдяки оперативній та точній доповіді командира, українська артилерія знищила мінометні позиції противника, тим самим зупинила обстріл селища 3 мирним населенням. Проте одним із останніх залпів противнику вдалося уразити спостережний пункт 93-ї окремої механізованої бригади, де перебував капітан 1 рангу Ю. Олефіренко. Ризикуючи власним життям, Юрій Борисович зіштовхнув в укриття трьох підлеглих військовослужбовців, закривши їх собою від осколків мінометної міни, яка вибухнула у кількох метрах від них - i дістав при цьому множинні тяжкі поранення, від яких помер дорогою до госпіталю. За особисту мужність і високий професіоналізм капітана 1 рангу
Ю. Олефіренка було нагороджено орденом Богдана Хмельницького III ступеня (посмертно) [19; 21; 22].

Аналіз досвіду проведення антитерористичної операції на території Донецької та Луганської областей у період 2014-2015 pр. засвідчив збільшення інтенсивності розвідувально-диверсійних дій противника малими мобільними групами. Російська Федерація безпосередньо здійснювала заходи щодо підтримки російсько-терористичних угруповань на території Донецької та Луганської областей шляхом поставок озброєння, матеріально-технічних засобів та інструкторського персоналу, у тому числі морським шляхом. Слід зазначити, що в умовах ведення “гібридної війни” РФ проти України Чорноморський флот у своєму складі має водолазів-розвідників спеціального призначення, технічні засоби їх доставки, спорядження, спеціальні міни, особисту зброю, навігаційні прилади, розвідувальну апаратуру i апаратуру зв'язку, призначені для розвідувально-диверсійних дій проти морських та берегових об'єктів ЗС України [23, с. 64-68].

Слід зазначити, що для розвідувально-диверсійних дій на приморському напрямку під керівництвом вищого військового керівництва Російської Федерації було проведено формування зведеного розвідувального загону спеціальної розвідки з місцем дислокації в районі н. п. Новоазовськ. До його складу увійшли водолази-розвідники з морських розвідувальних пунктів Тихоокеанського та Північного флотів ВМФ 
Російської Федерації. Виходячи 3 підготовки та можливостей розвідників мц СпП можна припустити, що саме вони 3 липня 2015 р. пострілом зі снайперської зброї ліквідували начальника штабу цього підрозділу [24].

Застосування військових частин спеціальної розвідки ВМФ РФ на приморському напрямку спонукає до здійснення заходів з організації протипідводно-диверсійного забезпечення Військово-Морських Сил в Азовському морі.

Підрозділи озаг бПДС3 ВМС ЗС України, починаючи з січня 2015 року залучались до ведення військової розвідки в інтересах військ морської піхоти у секторі “M", а не за прямим призначенням. Пропозиції керівництва загону щодо покращення розвідки з морського напрямку та організації протипідводно-диверсійного забезпечення командуванням штабу АТО у секторі "М" не приймалися до уваги. Особовий склад залучався до типових завдань військової розвідки, зокрема, виявлення стану та положення противника. На одному 3 таких завдань не обійшлось без втрат. Так, 2 березня 2015 р. розвідувальна група загону у складі 6 осіб на автомобілі потрапила у засідку російської диверсійно-розвідувальної групи поблизу с. Піщевик Маріупольського району. В результаті бойового зіткнення загинув старший сержант Стрелюк Олександр Олександрович, а мічман Стороженко Олег В'ячеславович помер дорогою до лікарні. Ще два офіцери отримали поранення. Обох загиблих бойових плав- ців було нагороджено орденами Богдана Хмельницького III ступеня (посмертно) $[4 ; 25]$.

У бойових діях на Дебальцевському плацдармі з 27 січня до 18 лютого 2015 року РГ СпП мц СпП ВМС ЗС України також брали безпосередню участь. Так, 31 січня 2015 року РГ СпП мц СпП разом із групою вогневої підтримки та групою БПЛА проводили розвідку в районі м. Вуглегірськ, який напередодні був зайнятий противником. За наказом Начальника Генерального штабу - Головнокомандувача ЗС України 1 лютого 2015 року РГ СпП мц СпП та інженерні групи були відправлені в район Світлодарська для недопущення захоплення противником дамби та мостів через річку Карапулька. Завдання групою було успішно виконано. 6 лютого 2015 року РГ СпП мц СпП в якості піхотного підрозділу брала участь у штурмі укріплень противника у сел Рідкодуб для деблокування взводного опорного пункту "Станіслав-128" окремої гірсько-піхотної бригади, обладнаний в районі зазначеного населеного пункту. В результаті деблокування взводного опорного пункту було виведено 102 військовослужбовці [26; 27].

3 метою недопущення оточення угруповання наших військ в районі Дебальцевого, відновлення його матеріально-технічного забезпечення командуванням АТО 10 лютого було прийнято рішення про проведення операції зі звільнення Логвинова від НЗФ. Для ведення розвідки та штурму Логвинова залучалася РГ СпП мц СпП. У період 3 
14 по 21 лютого 2015 р. під час підготовки і виведення військ сектору "C" 3 Дебальцевського плацдарму підрозділи мц СпП та полку СпП, що розташовувалися поруч, здійснювали охорону ділянки траси в районі с. Луганське для забезпечення безпечного виводу військ та протидії диверсійно-розвідувальним групам противника [26].

Після Дебальцева інтенсивність бойових зіткнень у ході АТО на території Донецької та Луганської областей значно знизилася. Обидві сторони перейшли до позиційної оборони. Слід зазначити, що противник почав широко застосовувати зброю, заборонену Мінськими угодами. Розвідники мц СпП активно залучались для пошуку та знищення мінометів та артилерії противника. Так, 2 червня 2015 р. поблизу села Чермалик РГ СпП під командуванням капітан-лейтенанта Горяйнова Михайла Геннадійовича здійснювала розвідувально-ударні дії щодо знищення 120 мм міномету противника, який постійно здійснював обстріл зазначеного населеного пункту. Під час запеклого бою $з$ противником, прикриваючи відхід групи, загинув капітан-лейтенант Горяйнов М. Г. За особисту мужність і високий професіоналізм його було нагороджено орденом Богдана Хмельницького III ступеня (посмертно) [19].

Протягом 2016 р. спостерігалося широке застосування диверсійно-розвідувальних сил російсько-терористичних угруповань вздовж всієї лінії зіткнення. В цей період часу на РГ СпП мц СпП покладалися завдання не тільки ведення військової розвідки, але і боротьба з диверсійно-розвідувальними групами (ДРГ) противника. Так, 4 березня 2016 р. у районі м. Докучаєвська РГ СпП мц СпП під час руху вздовж лінії зіткнення виявила ДРГ противника чисельністю до 20 осіб. Відстань між розвідниками та противником складала лише 20 м. Розвідники вступили в ближній бій з переважаючою за чисельністю ДРГ та знищили iii. Не обійшлось без втрат, під час бою загинули розвідники групи головний корабельний старшина Олександр Анатолійович Хмеляров та матрос Юрій Володимирович Горайський. За особисту мужність і високий професіоналізм обох розвідників було нагороджено орденами Богдана Хмельницького III ступеня (посмертно) [19; 28].

Основним завданням розвідників мц СпП стало здобування розвідувальної інформації щодо імовірного характеру дій противника. Під час виконання одного $з$ таких завдань, 5 вересня 2016 р. під час перетину лінії зіткнення на Маріупольському напрямку, загинув капітан 3 рангу Мединський Олег Костянтинович у районі м. Докучаєвська, підірвавшись на протипіхотній міні. Нагороджено орденом Богдана Хмельницького III ступеня (посмертно) [29].

Про успішне виконання бойових завдань флотськими розвідниками у ході ATO на території Донецької та Луганської областей свідчать багаточисельні відзначення державними нагородами України офіцерів, матросів та старшин мц СпП [30; 31; 32]. 
Можна констатувати, що застосовування підрозділів мц СпП та озаг бПДС3 ВМС 3С України у ході антитерористичної операції на території Донецької та Луганської областей проводилось не за прямим призначенням. Незважаючи на поставлені не притаманні водолазам-розвідникам та бойовим плавцям бойові завдання, вони всі були успішно виконані, а особовий склад отримав величезний бойовий досвід. В означений період мц СпП було втрачено 10 військовослужбовців, 3 яких 6 офіцерів у т. ч. 2 командири військової частини, озаг бПДС3 - 2 військовослужбовці.

Висновок: Аналіз досвіду застосування частин спеціального призначення ВMC 3С України під час АTO на території Донецької та Луганської областей у період 2014-2016 рр. засвідчив, що вони залучалися до виконання непритаманних завдань. Водолази-розвідники мц СпП разом із виконанням завдань спеціальної та військової розвідки на сухопутному напрямку залучалися до виконання типових завдань військових частин та підрозділів Сухопутних військ, таких як ведення наступальних боїв під час штурмів взводних опорних пунктів противника, ведення боїв зі звільнення міст (населених пунктів), охорони керівного складу АТО та інших. Бойові плавці озаг бПДСЗ виконували завдання військової розвідки в інтересах оперативно-тактичного угруповання у секторі “"M".

Доцільно враховувати, що підготовка кваліфікованого водолаза-розвідника або бойового плавця триває не менше двох календарних років. Тому військові частини та підрозділи спеціального призначення ВМС 3С України рекомендується застосовувати в операції Об’єднаних сил лише за їх призначенням та виконувати притаманні їм бойові завдання 3 морського напрямку. Це дозволить ефективно виконувати завдання за призначенням та максимально знизити втрати особового складу.

Подальші дослідження доцільно спрямувати на врахування бойового досвіду частин спеціального призначення ВМС 3С України в АТО на території Донецької та Луганської областей під час реформування відповідних військових частин флоту.

\section{Список використаних джерел і літератури}

1. Указ Президента України № 240/2016 Про рішення Ради національної безпеки і оборони України від 20 травня 2016 року “Про Стратегічний оборонний бюлетень України”.

2. План дій щодо впровадження оборонної реформи у 2019-2020 рр., затверджений Міністром оборони України від 23 січня 2019 року.

3. Жирохов М. История участия 73 морского центра специального назначения в войне на Донбассе (2014-2016 гг.) - Чернигов, 2019. - 84 с.

4. Шара А. Врятувати рядового “ластоного”: [Електрон. ресурс]. - Режим доступу: https:// tyzhden.ua/Society/157737. 
5. Фролов С. М. Створення та розвиток Українських підводних розвідувально-диверсійних сил та засобів. Воєнна історія: науково-популярний журнал. - 2013. Вип. 1. (67) С. 97-103.

6. Фролов С. М. Створення та розвиток у Військово-Морських Силах Збройних Сил України окремого загону боротьби з підводними диверсійними силами (2001-2018). Воєнно-історичний вісник. - 2019. Вип. 3. (33) С. 74-84.

7. Деревенченко О. Спогади про визволення Дзержинська. Флот України. 23.11.2014. № 30: [Електрон. ресурс]. - Режим доступу: http://fleet.sebastopol.ua/articles/spogadi_pro_vizvolennja_ dzerzhinska/.

8. Офіцери, учасники АТО обурені “інформаційною війною”, яка ведеться проти керівництва Міноборони та Генштабу ЗС України: [Електрон. ресурс]. - Режим доступу: http://www. mil.gov.ua/news/2014/10/08/oficzeri-uchasniki-ato-obureni-informaczijnoyu-vijnoyu-yaka-vedetsyaproti-kerivnicztva-minoboroni-ta-genshtabu-zs-ukraini/.

9. “33 бійці і 8 спецназівців групи прикриття утримали бойовиків і підняли український прапор", - два роки тому було звільнено місто Торецьк (Дзержинськ): [Електрон. ресурс]. - Режим доступу: ВІДЕО https://ua.censor.net.ua/video_news/398482/33_biyitsi_i_8_spetsnazivtsiv_grupy_ prykryttya_utrymaly_boyiovykiv_i_pidnyaly_ukrayinskyyi_prapor_dva.

10. Президент нагородив воїнів за подвиги в зоні АТО: [Електрон. ресурс]. - Режим доступу: http://www.mil.gov.ua/news/2014/08/08/prezident-nagorodiv-voiniv-za-podvigi-v-zoni-ato/.

11. Вклоняємось доземно українському солдату. - К.: Народна армія, 2014. - 192 с.

12. Северский В. "Морские котики" в донбасских степях: [Електрон. ресурс]. - Режим доступу: https://petrimazepa.com/spnseals.html.

13. 73-й морской центр специального назначения в боях на Донбассе: [Електрон. ресурс]. Режим доступу: https://colonelcassad.livejournal.com/3767885.html.

14. Нагорода знайшла свого героя // Флот України. 08.10.2014. № 26: [Електрон. ресурс]. Режим доступу: http://fleet.sebastopol.ua/articles/nagoroda_znajshla_svogo_geroja/.

15. Поповнення у лавах орденоносців Військово-Морських Сил Збройних Сил України: [Електрон. ресурс]. - Режим доступу: http://www.mil.gov.ua/news/2014/10/01/popovnennya-ulavah-ordenonoscziv-vijskovo-morskih-sil-zbrojnih-sil-ukraini/.

16. Завтонов О. “Дякую усім за допомогу та турботу!” // Флот України. 26.10.2014. № 28: [Електрон. peсурс]. - Режим доступу: http://fleet.sebastopol.ua/articles/djakuju_usim_ za_dopomogu_ta_turbotu/.

17. Аналіз бойових дій в районі Іловайська після вторгнення російських військ 24-29 серпня 2014 року: [Електрон. ресурс]. - Режим доступу: http:/www.mil.gov.ua/news/2015/10/19/analizillovausk--14354/.

18. Тинченко Я. Іловайськ: цифри і факти: [Електрон. ресурс]. - Режим доступу: http:// tyzhden.ua/Society/122995.

19. Книга пам'яті полеглих за Україну. 73 морський центр спеціального призначення. // 73 мцсо - Книга пам'яті загиблих: [Електрон. ресурс]. - Режим доступу: http://memorybook.org.ua/ units/seal.htm. 
20. ОО "Офицерский корпус" сообщил об освобождении из плена еще 7 украинских военных: [Електрон. ресурс]. - Режим доступу: http://infoline.ua/main/ukraine/OO--Oficerskiykorpus--soobschil-ob-osvobozhdenii-iz-plena-esche-7-ukrainskih-voennyh_15247.html.

21. Великий воїн України: [Електрон. ресурс]. - Режим доступу: http://www.gur.mil.gov.ua/ content/velikiy-voin-ukrainu.html.

22. Президент відзначив державними нагородами військових ЗСУ за особисту мужність і високий професіоналізм: [Електрон. ресурс]. - Режим доступу: http://www.mil.gov. ua/news/2015/04/11/prezident-vidznachiv-derzhavnimi-nagorodami-vijskovih-zsu-za-osobistumuzhnist-i-visokij-profesionalizm--/

23. Фролов С. М., Смагулов М. С. Морські диверсійно-розвідувальні сили і засоби Чорноморського флоту Російської Федерації. Морська стратегія держави. Розвиток та реалізація морського потенціалу України: матеріали міжнародного наукового форуму, 24-25 травня 2016 року. - К.: НУОУ ім. Івана Черняховського, 2016. - 216 с., С.64-68.

24. В Новоазовске убит начальник Штаба морских котиков России: [Електрон. ресурс]. - Режим доступу: http://www.0629.com.ua/news/878149.

25. Книга пам'яті полеглих за Україну. 801-й окремий загін боротьби з підводними диверсійними силами та засобами: [Електрон. ресурс]. - Режим доступу: http://memorybook.org.ua/21/ storozhenko.htm, http://memorybook.org.ua/21/streluk.htm.

26. Аналіз Генерального штабу ЗСУ щодо бойових дій на Дебальцевському плацдармі з 27 січня до 18 лютого 2015 року: [Електрон. ресурс]. - Режим доступу: http://www.mil. gov.ua/analitichni-materiali/analiz-generalno-shtabu-zsu-shhodo-bojovih-dij-na-debalczevskomuplaczdarmi-z-27-sichnya-do-18-lyutogo-2015-roku.html.

27. Сили спеціальних операцій Збройних сил України: [Електрон. ресурс]. - Режим доступу: https://ukrsof.com/73seal/.

28. Батьківщина понад усе: Останній бій воїнів 73-го центру спецоперацій 4 березня 2016 року: [Електрон. ресурс]. - Режим доступу: http://patrioty.org.ua/blogs/batkivshchynaponad-use-ostannii-bii-voiniv-73-ho-tsentru-spetsoperatsii-4-bereznia-2016-roku-111175.html.

29. Тяжелые новости с фронта. У сил АТО серьезные потери: [Електрон. ресурс]. - Режим доступу: http://kriminal.tv/news/tjazhelye_novosti_s_fronta_u_sil_ato_sreznye_poteri.html.

30. Миколаїв став надійним форпостом України на півдні - Президент: [Електрон. ресурс]. Режим доступу:http:/www.mil.gov.ua/news/2015/04/25/mikolaiv-stav-nadijnim-forpostom-ukrainina-pivdni-prezident--/.

31. “Бажаю усім нагородженим єдності та упевненості у перемозі!” - Міністр оборони України генерал-полковник Степан Полторак: [Електрон. pecypc]. - Режим доступу:http://www.mil. gov.ua/news/2015/07/05/bazhayu-usim-nagorodzhenim-ednosti-ta-upevnenosti-u-peremozi!-ministroboroni-ukraini-general-polkovnik-stepan-poltorak--11337/.

32. Указ Президента України №313/2016 від 29 липня 2016 року “Про відзначення державними нагородами України”: [Електрон. ресурс]. - Режим доступу:http://www.president.gov.ua/ documents/3132016-20337. 


\section{References}

1. Ukaz Prezydenta Ukrayiny № 240/2016 Pro rishennya Rady natsionalnoyi bezpeky i oborony Ukrayiny vid 20 travnya 2016 roku "Pro Stratehichnyy oboronnyy byuleten Ukrayiny".

2. Plan diy shchodo vprovadzhennya oboronnoyi reformy u 2019-2020 rr. zatverdzhenyy Ministrom oborony Ukrayiny vid 23 sichnya 2019 roku.

3. Zhyrokhov M. Ystoryya uchastyya 73 morskoho tsentru spetsialnoho naznachenyya v voyne na Donbasse (2014-2016 hh.). - Chernihiv, 2019. - 84 s.

4. Shara A. Vryatuvaty ryadovoho "lastonoho": [Elektron. resurs]. - Rezhym dostupu: https://tyzhden.ua/Society/157737.

5. Frolov S.M. Stvorennya ta rozvytok Ukrayinskykh pidvodnykh rozviduvalno-dyversiynykh syl ta zasobiv. Voyenna istoriya: naukovo-populyarnyy zhurnal. - 2013. Vyp. 1. (67) S. 97-103. 6. Frolov S.M. Stvorennya ta rozvytok u Viyskovo-Morskykh Sylakh Zbroynykh Syl Ukrayiny okremoho zahonu borotby z pidvodnymy dyversiynymy sylamy (2001-2018). Voyenno-istorychnyy visnyk. 2019. Vyp. 3. (33) S. 74-84.

7. Derevenchenko O. Spohady pro vyzvolennya Dzerzhynska. Flot Ukrayiny. 23.11.2014. № 30: [Elektron. resurs]. - Rezhym dostupu: http://fleet.sebastopol.ua/articles/spogadi_pro_vizvolennja_dzerzhinska/.

8. Ofitsery, uchasnyky ATO, obureni “informatsiynoyu viynoyu”, yaka vedetsya proty kerivnytstva Minoborony ta Henshtabu ZS Ukrayiny: [Elektron. resurs]. - Rezhym dostupu: http://www.mil.gov. ua/news/2014/10/08/oficzeri-uchasniki-ato-obureni-informaczijnoyu-vijnoyu-yaka-vedetsya-protikerivnicztva-minoboroni-ta-genshtabu-zs-ukraini/.

9. "33 biytsi i 8 spetsnazivtsiv hrupy prykryttya utrymaly boyovykiv i pidnyaly ukrayinskyy prapor", - dva roky tomu bulo zvilneno misto Toretsk (Dzerzhynsk): [Elektron. resurs]. - Rezhym dostupu: VIDEO https://ua.censor.net.ua/video_news/398482/33_biyitsi_i_8_spetsnazivtsiv_grupy_ prykryttya_utrymaly_boyiovykiv_i_pidnyaly_ukrayinskyyi_prapor_dva.

10. Prezydent nahorodyv voyiniv za podvyhy v zoni ATO: [Elektron. resurs]. - Rezhym dostupu: http://www.mil.gov.ua/news/2014/08/08/prezident-nagorodiv-voiniv-za-podvigi-v-zoni-ato/.

11. Vklonyayemos dozemno ukrayinskomu soldatu. - K.: Narodna armiya, 2014. - 192 s. 12. Severskyy V. "Morskye kotyky" v donbasskykh stepyakh: [Elektron. resurs]. - Rezhym dostupu: https:// petrimazepa.com/spnseals.html.

13. 73-y morskoy tsentr spetsyalnoho naznachenyya v boyakh na Donbasse: [Elektron. resurs]. Rezhym dostupu: https://colonelcassad.livejournal.com/3767885.html.

14. Nahoroda znayshla svoho heroya // Flot Ukrayiny. 08.10.2014. № 26: [Elektron. resurs]. Rezhym dostupu: http://fleet.sebastopol.ua/articles/nagoroda_znajshla_svogo_geroja/.

15. Popovnennya u lavakh ordenonostsiv Viyskovo-Morskykh Syl Zbroynykh Syl Ukrayiny: [Elektron. resurs]. - Rezhym dostupu: http://www.mil.gov.ua/news/2014/10/01/popovnennya-u-lavah-ordenonoscziv-vijskovo-morskih -sil-zbrojnih-sil-ukraini/.

16. Zavtonov O. "Dyakuyu usim za dopomohu ta turbotu!” // Flot Ukrayiny. 26.10.2014. № 28: 
[Elektron. resurs]. - Rezhym dostupu: http://fleet.sebastopol.ua/articles/djakuju_usim_za_dopomogu_ ta_turbotu/.

17. Analiz boyovykh diy v rayoni Ilovayska pislya vtorhnennya rosiyskykh viysk 24-29 serpnya 2014 roku: [Elektron. resurs]. - Rezhym dostupu: http://www.mil.gov.ua/news/2015/10/19/analiz-illovausk--14354/.

18. Tynchenko YA. Ilovaysk: tsyfry i fakty: [Elektron. resurs]. - Rezhym dostupu: http://tyzhden. ua/Society/122995.

19. Knyha pamyati polehlykh za Ukrayinu. 73 morskyy tsentr spetsialnoho pryznachennya. // 73 mtssso - Knyha pamyati zahyblykh: [Elektron. resurs]. - Rezhym dostupu: http://memorybook.org. ua/units/seal.htm.

20. OO "Ofytserskyy korpus" soobshchyl ob osvobozhdenyy yz plena eshche 7 ukraynskykh voennykh: [Elektron. resurs]. - Rezhym dostupu: http://infoline.ua/main/ukraine/OO--Oficerskiy-korpus-soobschil-ob-osvobozhdenii-iz-plena-esche-7-ukrainskih-voennyh_15247. html.

21. Velykyy voyin Ukrayiny: [Elektron. resurs]. - Rezhym dostupu: http://www.gur.mil.gov.ua/ content/velikiy-voin-ukrainu.html.

22. Prezydent vidznachyv derzhavnymy nahorodamy viyskovykh ZSU za osobystu muzhnist i vysokyy profesionalizm: [Elektron. resurs]. - Rezhym dostupu: http://www.mil.gov.ua/news/2015/04/11/prezidentvidznachiv-derzhavnimi-nagorodami-vijskovih-zsu-za-osobistu-muzhnist-i-visokij-profesionalizm--/

23. Frolov S.M., Smahulov M.S. Morski dyversiyno-rozviduvalni syly i zasoby Chornomorskoho flotu Rosiyskoyi Federatsiyi. Morska stratehiya derzhavy. Rozvytok ta realizatsiya morskoho potentsialu Ukrayiny: materialy mizhnarodnoho naukovoho forumu, 24-25 travnya 2016 roku. - K.: NUOU im. Ivana Chernyakhovskoho, 2016. - 216 s., S.64-68.

24. V Novoazovske ubyt nachalnyk Shtaba morskykh kotykov Rossyy: [Elektron. resurs]. Rezhym dostupu: http://www.0629.com.ua/news/878149.

25. Knyha pamyati polehlykh za Ukrayinu. 801-y okremyy zahin borotby z pidvodnymy dyversiynymy sylamy ta zasobamy: [Elektron. resurs]. - Rezhym dostupu: http://memorybook.org.ua/21/ storozhenko.htm, http://memorybook.org.ua/21/streluk.htm.

26. Analiz Heneralnoho shtabu ZSU shchodo boyovykh diy na Debaltsevskomu platsdarmi z 27 sichnya do 18 lyutoho 2015 roku: [Elektron. resurs]. - Rezhym dostupu: http://www.mil.gov.ua.

27. Syly spetsialnykh operatsiy Zbroynykh syl Ukrayiny: [Elektron. resurs]. - Rezhym dostupu: https://ukrsof.com/73seal/.

28. Batkivshchyna ponad use: Ostanniy biy voyiniv 73-ho tsentru spetsoperatsiy 4 bereznya 2016 roku: [Elektron. resurs]. - Rezhym dostupu: http://patrioty.org.ua/blogs/batkivshchyna-ponad-useostannii-bii-voiniv-73-ho-tsentru-spetsoperatsii-4-bereznia-2016-roku-111175.html. 29. Tyazhelye novosty s fronta. U syl ATO sereznye potery: [Elektron. resurs]. - Rezhym dostupu: http://kriminal.tv/ news/tjazhelye_novosti_s_fronta_u_sil_ato_sreznye_poteri.html.

30. Mykolayiv stav nadiynym forpostom Ukrayiny na pivdni - Prezydent: [Elektron. resurs]. Rezhym dostupu: http://www.mil.gov.ua/news/2015/04/25/mikolaiv-stav-nadijnim-forpostom-ukrainina-pivdni-prezident--/. 
31. "Bazhayu usim nahorodzhenym yednosti ta upevnenosti u peremozi!" - Ministr oborony Ukrayiny heneral-polkovnyk Stepan Poltorak: [Elektron. resurs]. - Rezhym dostupu: http://www.mil. gov.ua/news/2015/07/05/bazhayu-usim-nagorodzhenim-ednosti-ta-upevnenosti-u-peremozi!-ministroboroni-ukraini-general-polkovnik-stepan-poltorak--11337/.

32. Ukaz Prezydenta Ukrayiny №313/2016 vid 29 lypnya 2016 roku "Pro vidznachennya derzhavnymy nahorodamy Ukrayiny": [Elektron. resurs]. - Rezhym dostupu: http://www.president.gov. ua/documents/3132016-20337.

Frolov S. M., captain (N) phd of historical sciences, Associate Professor of the Department of the Navy

\section{USING OF THE UKRAINE SPECIAL OPERATIONS NAVAL FORCES OF THE ARMED FORCES OF UKRAINE ON THE ANTI-TERRORIST OPER- ATION IN THE DONETSK AND LUHANSK REGIONS (2014-2016 PP.)}

In the context of the operation of the Joint Forces in the Donetsk and Luhansk regions, one of the priority and urgent issues in the development of the Naval Forces of the Armed Forces of Ukraine is the development Special Forces Navy.

Experience of fighting of the anti-terrorist operation in the Donetsk and Luhansk regions demonstrated widespread use Special Forces Navy of the Naval Forces of the Armed Forces of Ukraine in particular special purpose marine center and of separate special anty sabatage team of the Ukrainian Navy.

The relevance of this topic is necessitated by the need to study the experience of applying units special purpose marine center and of separate special anty sabatage team of the Ukrainian Navy of the anti-terrorist operation in the Donetsk and Luhansk regions which, in our opinion, is the basis for further action is the development special purpose military units.

The author proposes to cover the experience of using units on the basis of open sources special purpose marine center and of separate special anty sabatage team of the Ukrainian Navy of the anti-terrorist operation in the Donetsk and Luhansk regions and provide guidance on how to apply them in today's context.

The tasks assigned to the aforementioned units are analyzed. It was established which personnel of the special purpose units of the Navy of the Armed Forces of Ukraine were awarded state awards for the accomplishment of combat and special tasks. The combat losses of the personnel of the Special Forces of the Navy of the Armed Forces of Ukraine are covered.

Recommendations are given on the use of units of special purpose units of the 
Navy of the Armed Forces of Ukraine in the current conditions.

The combat experience of the Special Forces Navy of the Armed Forces of Ukraine in the anti-terrorist operation on the territory of Donetsk and Luhansk regions will allow to avoid shortcomings and miscalculations during the reform of the respective units of the fleet.

Keywords: application, special purpose marine center, separate special anty sabatage team, the Navy of the Armed Forces of Ukraine, anti-terrorist operation, military intelligence. 